\title{
EFFECT OF AYURVEDIC DRUG COMBINATION IN MANAGEMENT OF HYPOTHYROIDISM - A CASE STUDY
}

\author{
Dr. Darshana D Khadtale ${ }^{*} \bowtie$, Dr. Minal S Vaidya \\ ${ }^{* 1}$ PG Scholar Kayachikitsa Department, YMT Ayurvedic Medical College and Hospital Kharghar \\ 410210 \\ ${ }^{2}$ HOD Professor and PG Guide Kayachikitsa Department, YMT Ayurvedic Medical College and \\ Hospital Kharghar 410210
}

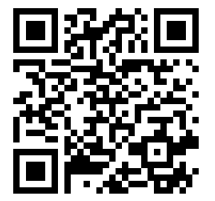

DOI: https://doi.org/10.29121/granthaalayah.v8.i7.2020.812

Article Type: Case Study

Article Citation: Dr. Darshana D Khadtale, and Dr. Minal S Vaidya. (2020). EFFECT OF AYURVEDIC DRUG COMBINATION IN MANAGEMENT OF HYPOTHYROIDISM - A CASE

STUDY. International Journal of Research -GRANTHAALAYAH, 8(7), 410-414.

https://doi.org/10.29121/granthaa layah.v8.i7.2020.812

Received Date: 16 July 2020

Accepted Date: 31 July 2020

Keywords:

Gandamala

Granthi

Strotas

Parshav

HYPOTHYROIDISM

\begin{abstract}
Thyroid gland does not produce enough thyroid hormone, called Hypothyroidism. Hypothyroidism is the disorder of the endocrine system. Modern treatment is not as much effective and preventive as compare to Ayurvedic management of hypothyroidism. In the text of Ayurveda there is not direct reference of thyroid but whereas the Gandmala and Galganda. As per charak presentation, gandamala is the multiple granthi around the neck while galganda is single swelling on the parshav of the neck. While analysing the signs and symptoms of hypothyroidism in ayurvedic view, we note there is involvement of all strotas but dominantly Rasvah Strotus. A single case study of patient 36 years female newly diagnosed with hypothyroidism presenting with symptoms weight gain, irregular menstrual cycle, stress, swelling over face since 3 months and presented in outpatient department of Y.M.T trust's ayurvedic hospital on 13th sep 2019 after patients blood investigation her TSH level on 15th sep 2019 was 14.57 and after treatment on 18th nov 2019 her TSH level was normal i.e 2.55. Hence, ayurvedic drugs of choice is more useful and best treatment in hypothyroidism.
\end{abstract}

\section{INTRODUCTION}

Hypothyroidism is the most common problem in today's modern world. The prevalence of hypothyroidism in india is 11\% [1] . It is the most common disorder in daily OPD. The global incidence of hypothyroidism is increasing and disturbing way as people are exposed to more stress and strain. Weight gain, fatigue, cold intolerance, hoarseness of voice, puffiness of face are the symptoms of hypothyroidism. [2] Triiodothyronine (T3) and tetraiodothyronine or thyroxine(T4) are the two hormones secreted by thyroid gland. In hypothyroidism less secretion of T3 and T4 because of there is abnormal functioning of thyroid gland. In females the disease is more common. The ratio of male female is approximately $6: 1 \cdot[3]$

In Tridoshiya Adhyaya of sutra -sthana chapter 18 Galganda, gandamala etc are described by Acharya Charak but the proper knowledge of this disease is not understood. The concept of Sotha in Chikitsa- Sthana also explained by Acharya Charak [4]. In Ayurveda galganda and gandamala are correlated with the disorder caused by thyroid

(C) 2020 The Author(s). This is an open access article distributed under the terms of the Creative Commons Attribution License, which permits unrestricted use, distribution, and reproduction in any medium, provided the original author and source are credited. 
gland. In Ayurveda disturbance of meda and majja dhatus results in formation of galganda when there is vitiation of vaat and kapha doshas, predominantly kapha. In pathogenesis dushti of rasdhatu plays a major role. Clinical features of hypothyroidism i.e asradhdha, aruchi, gaurava, tandra, angamarda, agnimandya etc. are similar to many rasdhatu dushti lakshane. Hormonal disturbance are the dysfunction of agni.

Signs and symptoms of hypothyroidism with an ayurvedic approach.

1) Anorexia- It shows symptoms like kapha dosha and ras dhatu dushti due to mandagni.

2) Constipation- According to ayurveda, the Anuloma gati of mala and vayu gets to slow down and increase the manda guna of kapha.

3) Weight Gain- The weight gain occur, because of guru guna of kapha and pruthavi and jala mahabhuta involved in kapha dosha.

4) Hoarseness of voice- Due to increase in manda guna of kapha, hoarseness of voice appears.

5) Anaemia- According to Ayurveda, rasa dhatudushti as well as kapha dushti results in panduta.

6) Dry skin- Dryness of skin occurs because enhanced ras cannot narishes rakta dhatu.

7) Bradycardia- Propagation of kapha with its mandaguna may result due to Bradycardia.

8) Excessive sleep- Tandra and atinidra are results of kapha vridhi.

9) Myxedema- Because of sthira guna of kapha dosha this non pitting type of oedema found in hypothyroidism.

10) Menstrual Distrubance- The nourishment of upadhatu artava and uttar dhatu rakta may be unabled because of the rasa dhatu dushti. As a result of this artava pravriti may be disturbeds

In the hypothyroiudism all the symptoms indicates the involvement of kapha, dosha, rasa dhatu and rasa dhatvangni. In the disease hypothyroidism all the kapha dosha plays important role.

\section{CASE DESCRIPTION}

A 36 years old females newly diagnosed with hypothyroidism presenting with weight gain, irregular menstrual cycle, constipation, dryskin, stress, swelling over face, anaemia, excessive sleep since 3 months and presented in out patient department of Y.M.T. trust's ayurvedic hospital on 13 september 2019.

- Ashtavidha Parikshansa

- $\quad$ Nadi (pulse) $=80 / \mathrm{min}$

- Mala (stool) = Malavshtmbha

- $\quad$ Mutra (urine) $=$ Normal

- Jeeva (tounge) = Saam

- Shabda $($ speech $)=$ Spastha $($ Normal)

- $\quad$ Sparsha ( skin) = Ruksha

- $\quad$ Druka (eyes) = Alpa aaraktavarni

- $\quad$ Aakruti = Stula

\section{AIM}

To assess the probable mode of action of ayurvedic drug combination in the management of hypothyroidism.

\section{OBJECTIVES}

Evaluated the effect of Kanchanar guggul, Aargyavardhini ras and Punarnava mandur in hypothyroidism. 


\section{MATERIALS AND METHOD}

\subsection{MATERIALS}

\begin{tabular}{|c|c|c|c|c|}
\hline Sr.No & Dravya & Dose & Duration & Anupana \\
\hline 1. & Kanchnar Guggul & $250 \mathrm{mg}$ & $500 \mathrm{mg}$ empty stomach & warm water \\
\hline 2. & Aarogyavardhini ras & $250 \mathrm{mg}$ & $500 \mathrm{mg}$ after food & warm water \\
\hline 3. & Punarnava mandur & $250 \mathrm{mg}$ & $500 \mathrm{mg}$ after food & warm water \\
\hline
\end{tabular}

\subsection{METHODS}

Single case study of patient with hypothyroidism was selected from OPD YMT Ayurvedic, Kharghar.

\section{DIAGNOSIS}

According to Ayurveda the patient clearly shows the symptoms of galganda such as rasa dhatu dushti lakshane and kapha dhatu dushti. So, it was a case of hypothyrouidism i.e galganda. patient was subjected to further investigations like $\mathrm{Hb}, \mathrm{T} 3, \mathrm{~T} 4$, TSH and since her TSH total was 14.57 in reports, hence we came to conclusion that she was suffering from hypothyroidism.

\section{OBSERVATION AND RESULT}

The patient was administered classical internal medication.There is no other allopathic treatment only combination of ayurvedic drugs are given to the patient. After starting Kanchanar guguul, Aarogyavardhini Ras and Punarnava Mandur tablets means oral medications her symptoms like constipation, heaviness, swelling over face, started to reduced over course of time. In between the medications her symptoms starts to improve. On 15/09/2019 patients TSH level was 14.57 and after two months on 18/11/2019 TSH level becomes normal i.e 2.55. Highly significant results observed in subjective and objective criteria.

\section{DISCUSSION}

Hypothyroidism needs to be treated as it is a clinical condition so cases should be treated patiently because like modern medicine, ayurvedic medicine also takes time to normalize the value of TSH. Only galganda and gandamala are found in the ayurveda text, there is no direct reference of hypothyroidism in the ayurveda text. Since galganda is vata kaphaja disorder hence the drugs used, act on vata and kapha and also symptoms wise treatment was given to patient.

Ayurveda provides promising treatment for the disease. Also, pathya and apathya management is important.

- Pathya- Light diet, food rich in vitamin A and D, Iodine rich diet. Increase in physical activities, aerobic exercises, in Yoga-Sarvangasan, Matsyasan, Halasan, Suryanamaskar found to be helpful. In Pranayama, most effective is Ujjayi Pranayama.

- Apathya- Cabbage, Cauliflower, Soyabeans, Pears, heavy-fried and fast food, over sleep.

\section{MODE OF ACTION}

\subsection{INTERNAL MEDICINE}

1) KANCHANAR GUGGUL- This drug was chosen because kanchnar guggul is considered as drug of choice for all kind of granthis. Rogadhikar of Kanchanar Guggul is Galganda and Gandamala. The excess kapha doshas in the body are balanced by the help of kanchnar guggul, even the swelling in neck, and in goiter is reduced. It also helps to reduce or break down the deep seated kapha and supports the digestive fire. Proper circulation of blood and elimination of toxins from body is also promoted by kanchnar guggul, 
hence it is called the best vata and medohara. It is effective in the management of kapha-medas predominant disorders like hypothyroidism because it possesses laghu (light), ruksha (dry), sukshma (minute) guna and ushna virya (hot potency), katu vipaka and lekhana property. Hence here drug of choice is kanchnar guggul. Dose- 2 tablets (500mg), Abhakta (empty stamoch). Kanchnar Guggul reference in Ayurveda- bhaishajya ratnavali galgandadirogchikitsa 44/64-69.

2) AAROGYAVARDHINI VATI- Aarogyavardhini vati is works on pachankriya. Aarogyavardhini vati is a formulation which improves good health. According to my opinion, due to stress of workload and mental stress of living with hypothyroidism, digestive upset due to faulty dietary habits and lifestyle may aggravates her disease condition. The holistic approach of ayurvedic system of medicine provided purification procedure like virechana procedure which removes the toxic waste materials from the body which helps in constipation and also boost the immune system. Dose- 2 tablets (500mg), after food. Aarogyavardhini Vati reference in ayurveda- Ras Ratna Samuchaya 20/87-93.

3) PUNARNAVA MANDUR- Punarnava mandur is a formulation which may works as a Rasayana in hypothyroidism, and also it helps in panduta, mainly punarnava mandur used in Rasa dhatu dushti, it helps to improve the sign and symptoms which is due to rasa dhatu dushti e.g panduta, aruchi, asradhdha, gaurava, tandra, angamarda, panduroga, agnimandya hence it is the important drug in hypothyroidism. Dose- 2 tablets (500mg) after food. Punarnava Mandur reference in ayurveda-Charak Samhita Chikitsa Sthana 16/93-95.

\section{SAMPRAPTI}

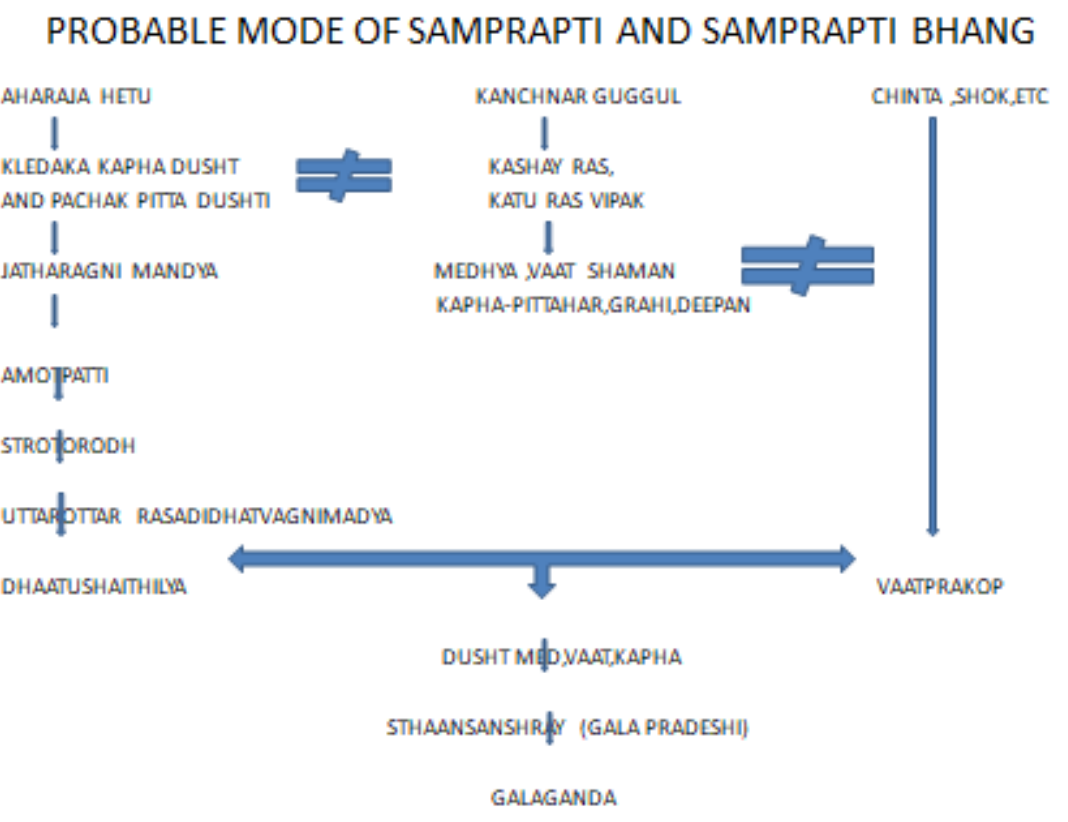

\section{CONCLUSION}

Hypothyroidism can be very well managed by ayurvedic medicine depending upon the symptoms, and careful selection of drugs to be made. Hence hypothyroidism should be ruled out at OPD level since it is the most prevalent disorder. One can not only decrese the level of TSH, but also enhance, stimulate the normal functioning of gland with ayurvedic treatment. No side effect or any complications were seen, because patient very well tolerated the treatment. Ayurvedic medicines are requested to be prescribe without any fear because it has proven to be bliss in thyroid disorder. Thus, Hypothyrooidism, the metabolic disorder can be managed effectively with the help of ayurvedic principles. 

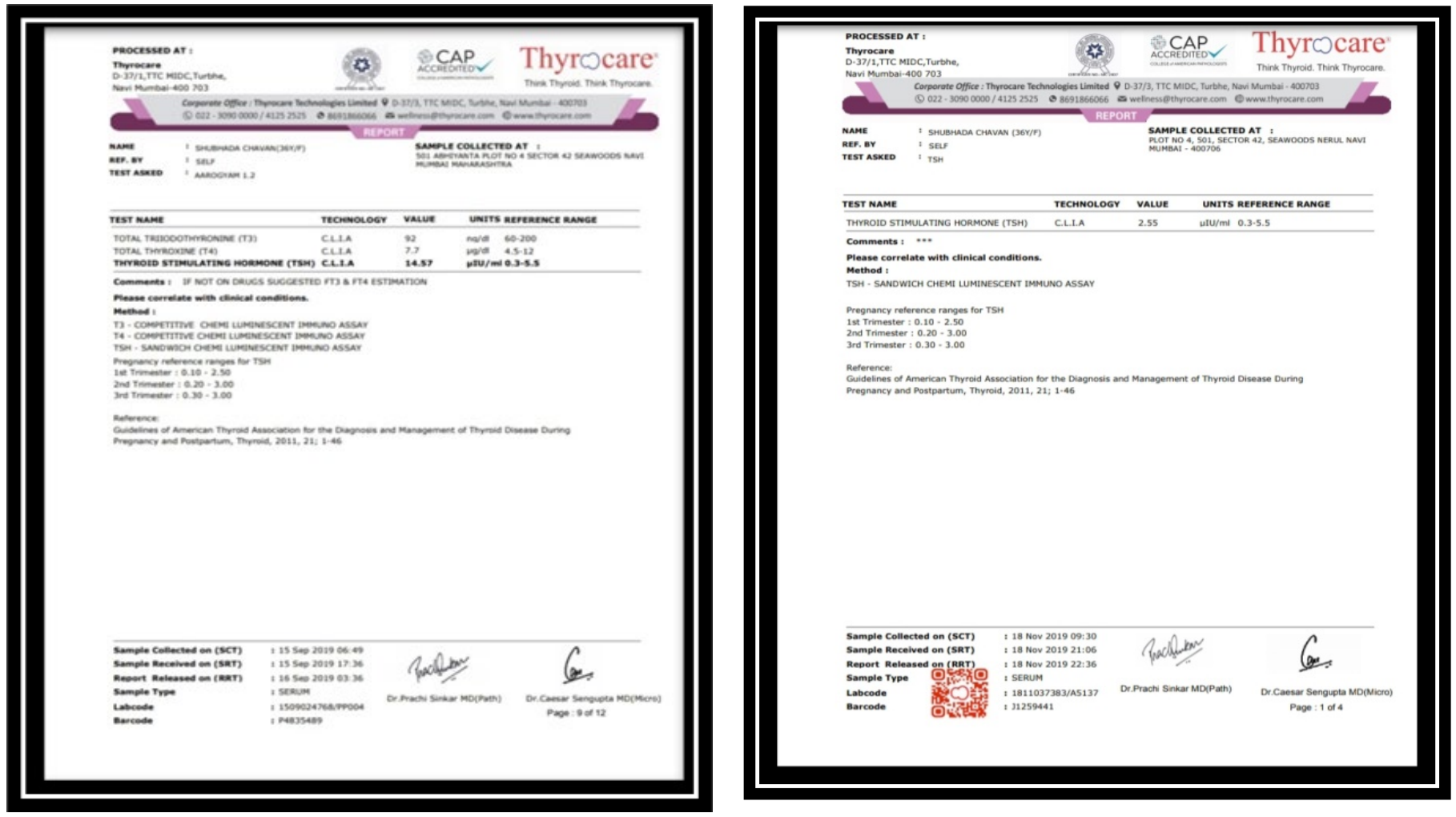

\section{SOURCES OF FUNDING}

This research received no specific grant from any funding agency in the public, commercial, or not-for-profit sectors.

\section{CONFLICT OF INTEREST}

The author have declared that no competing interests exist.

\section{ACKNOWLEDGMENT}

None.

\section{REFERENCES}

[1] www.thelancet.com

Date -30st july 2020, Time - 1:45 am

[2] Davidson's Edited by Edwards, Bouchier, Haslett, Principle and Practice of medicine Churchill Livingstone,17th edition,1995, Page no-685

[3] www.iamj.in

Date - 31st july 2020, Time - 10:00 pm

[4] Charak Samhita-Elaborated vidyotini hindi commentary part-2, by Pt. Kashinath Panday and Dr. Gorakhnath Chaturvedi, Chaukhamba Bharati Academy, Varanasi,2013, Chikitsa Sthana, Chapter 12

[5] www.ujconline.net

Date - 31st july 2020, Time - 12:20 pm 